\title{
Monitoring the Recovery of the Sparta Aquifer in Southern Arkansas and Northern Louisiana
}

The Sparta aquifer supplies the majority of water for industrial, municipal, and agricultural uses in Union County, Arkansas, and the surrounding area. In Union County, the Sparta aquifer has been used increasingly since development began in the early 1920 's, resulting in water-level declines of more than 360 feet (ft) in some areas. In addition, water quality of the Sparta aquifer has degraded in some areas as usage has increased. In response to the declining water levels and degraded water quality, the Arkansas Natural Resources Commission designated the Sparta aquifer as a "Critical Ground-Water Area" in five counties of southern Arkansas in 1996. Groundwater flow models developed by the U.S. Geological Survey (USGS) indicate that withdrawals from the Sparta aquifer in Union County must be reduced to 28 percent of 1997 withdrawals (about 6 million gallons per day $(\mathrm{Mgal} / \mathrm{d}))$ to maintain water levels at or above the top of the Sparta Sand (Hays, 2000).

\section{Background}

In 1999, Union County stakeholders petitioned the Governor to appoint a water conservation board, which was given taxing authority and began educating the public about declining ground-water levels. To prevent further water-level declines in the Sparta aquifer, stakeholders initiated conservation and reuse of ground water and tapped a surface-water supply as an alternative source for certain industrial uses. A pumping station and pipeline were built in 2004 to supply $10 \mathrm{Mgal} / \mathrm{d}$ from the Ouachita River to industrial users. By reducing ground-water withdrawals, water levels are expected to recover and water quality is expected to improve or stabilize as water use shifts away from the Sparta aquifer. With support from the U.S. Environmental Protection Agency, the Union County Water Conservation Board (UCWCB) implemented a study in 2003 with the USGS, Union County Conservation District (UCCD), and Burns \& McDonnell to monitor the impact of the conservation and alternative water efforts on the water-level and water-quality characteristics of the Sparta aquifer system (Yeatts, 2004).

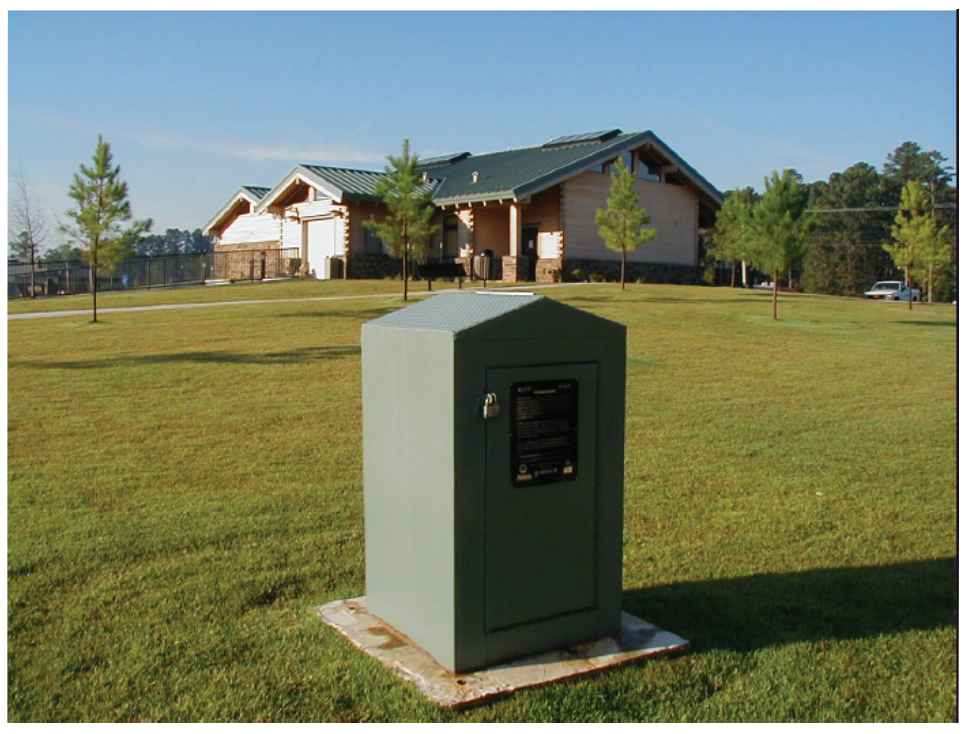

Figure 1. Real-time water-level site located at the Arkansas Welcome Center near El Dorado, Arkansas (photograph by Ralf Montanus, U.S. Geological Survey).

\section{Study Objectives}

The objectives of the study are to:

- Provide real-time and continuous recorder waterlevel data on the internet from a network of wells (figs. 1-2) to document water-level changes within the Sparta aquifer.

- Conduct semi-annual water-quality sampling from a network of wells withdrawing water from the Sparta aquifer to detect changes in specific conductance and chloride concentration.

The purpose of this report is to briefly summarize the ground-water data collection network of the USGS and the UCWCB, and present the USGS real-time waterlevel and water-quality information collected from July 2003-March 2006 in the study area of southern Arkansas and northern Louisiana. 


\section{Ground-Water Level Monitoring}

Real-time water-level monitoring is conducted by the USGS in eight wells (fig. 2). Continuous recorder water-level monitoring is conducted by the UCCD in nine wells (not shown on fig. 2). Ground-water level monitor wells were selected from existing wells or drilled in and around Union County to form a ground-water level monitoring network.

One of the criteria to be designated as a Critical Ground-Water Area in Arkansas is that water levels are below the top of the formation for an aquifer in a confined system. Water levels for seven of the eight real-time sites still show that the Sparta aquifer in the Union County, Arkansas, area continues to meet Critical Ground-Water Area criteria. As of March 2006, water levels in the Sparta aquifer range from $62.5 \mathrm{ft}$ above the top of the Sparta Sand to $96 \mathrm{ft}$ below the top of the Sparta Sand (fig. 2).
Water levels have risen 4 to $28 \mathrm{ft}$ (as of March 2006) in seven of the eight real-time wells since monitoring began in the summer of 2003 (fig.3). Water levels at the eighth well (Spencer) have neither increased nor decreased. In the winter of 2004, Ouachita River water was supplied to two major industrial users of ground water. From this implementation of surface water, ground-water usage decreased, and water levels increased as much as $28 \mathrm{ft}$ in the Monsanto well and as much as $15 \mathrm{ft}$ in the Airport well.

The internet based real-time water-level data and other data allow citizens and officials to quickly assess the changing water levels. The data can be accessed at:

Real-time water-level monitoringhttp://ar.water.usgs.gov/gw_choice.html

Continuous recorder water-level monitoringhttp://www.ucwcb.org

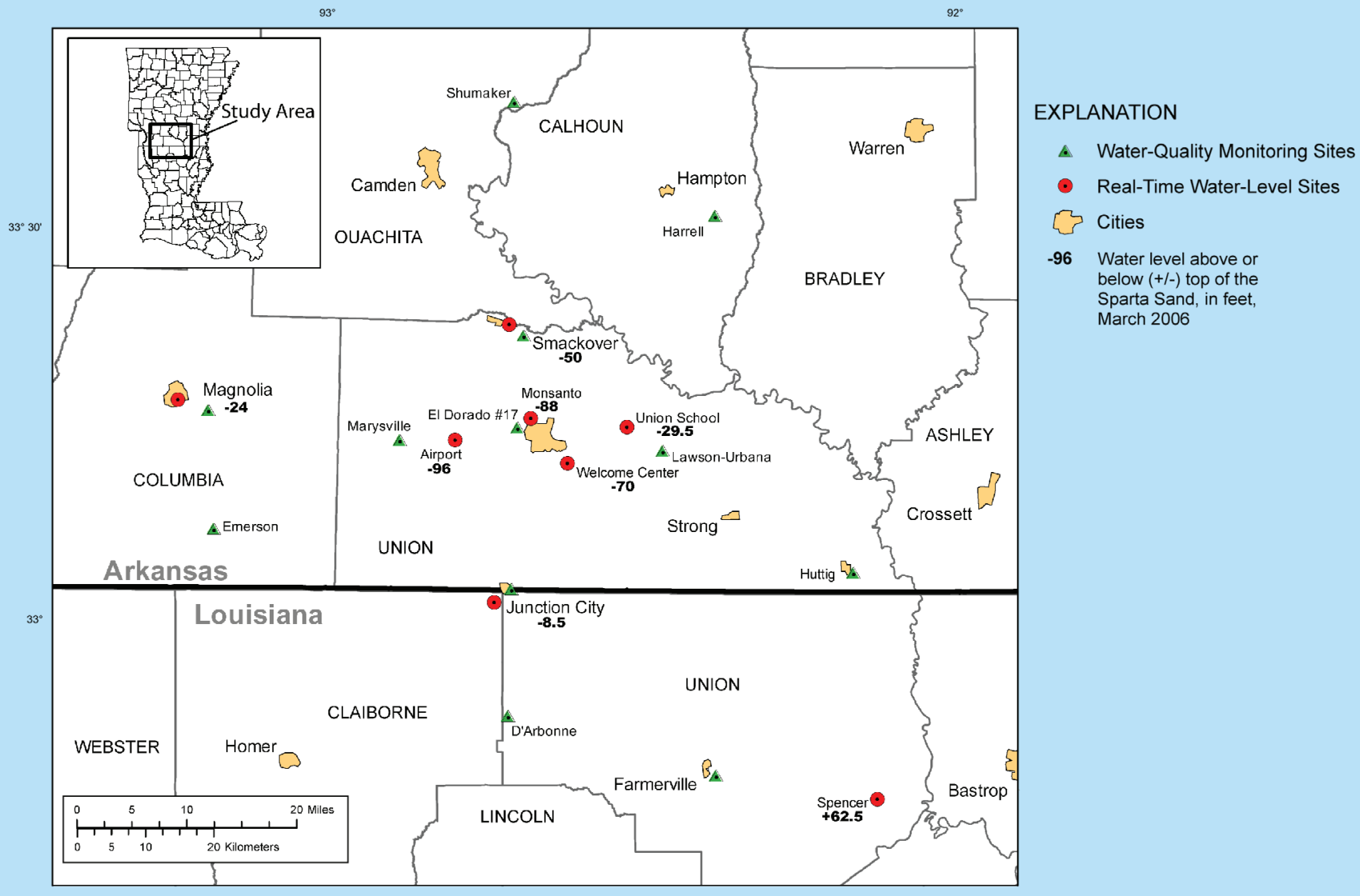

Figure 2. Location of real-time water-level and water-quality monitoring sites, and the difference between the altitude of the Sparta Sand top and the water level for the U.S. Geological Survey real-time water-level monitoring sites. 


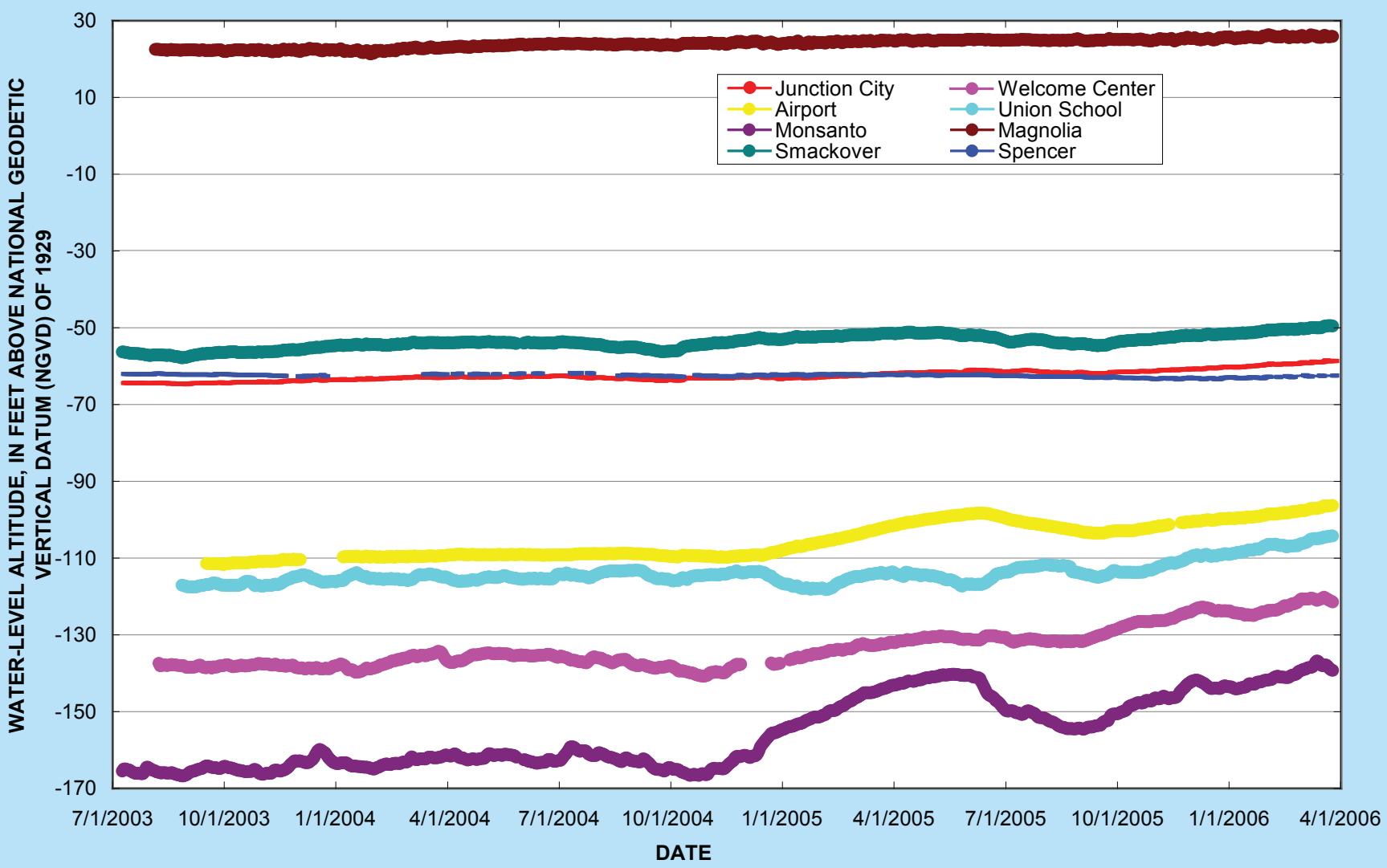

Figure 3. Hydrographs showing water levels for the U.S. Geological Survey real-time water-level monitoring sites.

\section{Water-Quality Monitoring}

Water-quality samples are collected from 12 existing public or industrial supply wells that are spatially distributed over the study area (fig. 2). The wells are sampled semi-annually (January and July) for chloride concentration, water temperature, and specific conductance. Changes in the concentrations of chloride in ground water are useful in determining areas affected by saltwater (high salinity water) encroachment. If enough freshwater is withdrawn from a ground-water system, water with higher salinity can flow into the system to replace the lost freshwater. The higher salinity water may flow upward from deeper systems as well as laterally from areas containing saltwater.

Specific conductance and chloride concentration increases toward the southeast in the Union County area. Median specific conductance ranges from 212 to 1,245 microsiemens per centimeter at 25 degrees
Celsius $(\mu \mathrm{S} / \mathrm{cm})$, and median chloride concentration ranges from 3 to 214 milligrams per liter $(\mathrm{mg} / \mathrm{L})$ based on 6 samples from each of the 12 wells (fig. 4). The U.S. Environmental Protection Agency's (EPA) National Secondary Drinking Water Regulation for chloride in public water supply is $250 \mathrm{mg} / \mathrm{L}$. Wells sampled in the northwestern part of the study area (Shumaker, Marysville, Magnolia, and Emerson) have median specific conductance values less than $400 \mu \mathrm{S} / \mathrm{cm}$ and median chloride concentration less than $10 \mathrm{mg} / \mathrm{L}$. Farmerville, Louisiana, and Huttig, Arkansas, in the southeastern part of the study area have the highest values with median specific conductance greater than 1,100 $\mu \mathrm{S} / \mathrm{cm}$ and median chloride concentration greater than $200 \mathrm{mg} / \mathrm{L}$. The results coincide with more regional specific conductance and chloride concentration results (Schrader, 2004). 


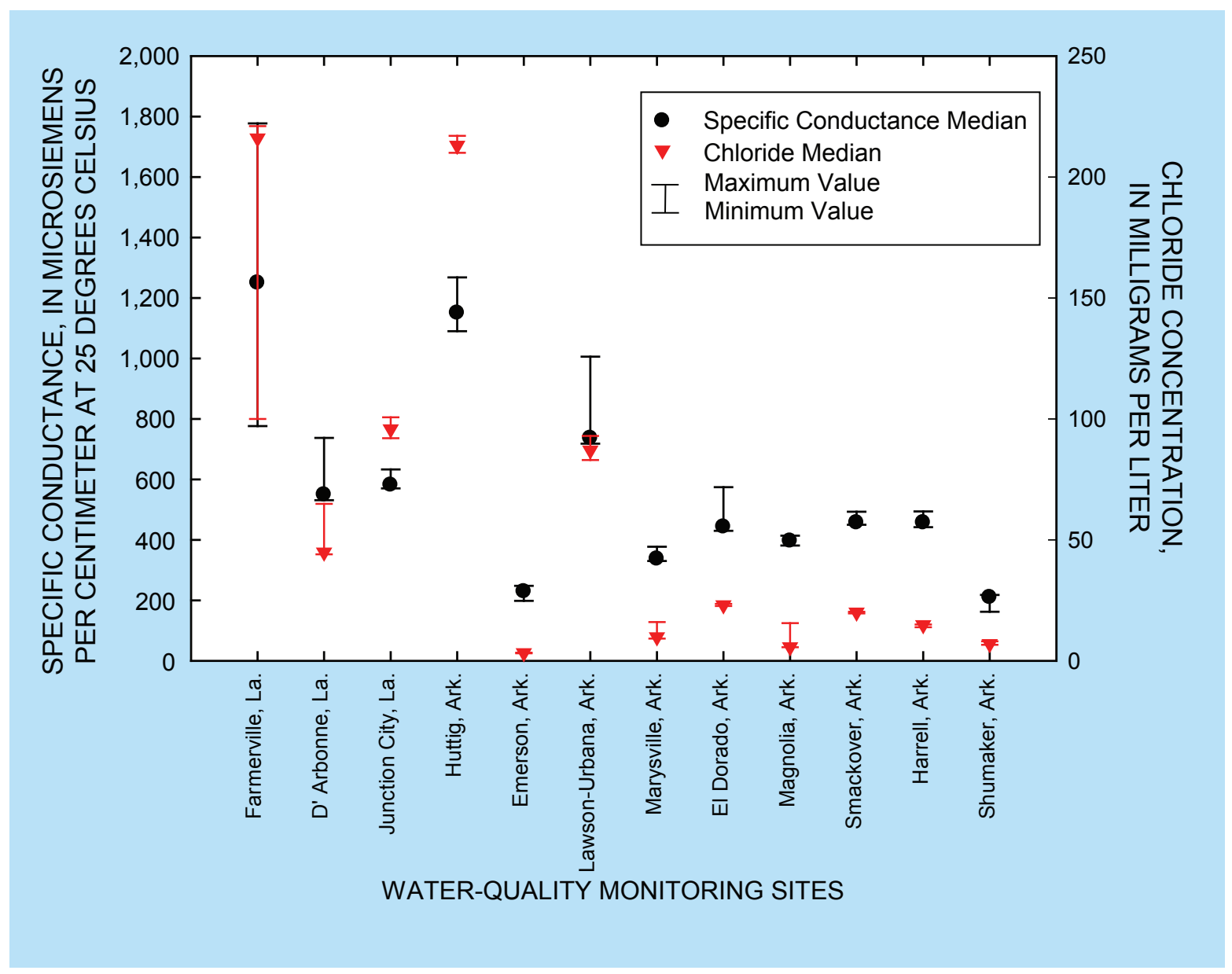

Figure 4. Specific conductance and chloride results for the U.S. Geological Survey water-quality monitoring sites.

\section{Selected References}

Brantly, J.A. and others, 2002 Louisiana groundwater map No. 13: hydrogeology and potentiometric surface, October 1996, of the Sparta aquifer in northern Louisiana: U.S. Geological Survey Water-Resources Investigations Report 02-4053, 3 plates.

Burns and McDonnell, 2005, Sparta aquifer recovery study, February 2005 - August 2005: 6th SemiAnnual Report, 32 p.

Hays, P.D., 2000, Sustainable yield estimation for the Sparta aquifer in Union County, Arkansas: U.S. Geological Survey Water-Resources Investigations Report 99-4272, 17 p.

Schrader, T.P., 2004, Status of water levels and selected water-quality conditions in the SpartaMemphis aquifer in Arkansas and the Sparta aquifer in Louisiana, spring-summer 2001: U.S. Geological Survey Scientific Investigations Report 2004-5055, 52 p.
Yeatts, D.S., 2004, Monitoring water-level and waterquality response to conservation measures in the Sparta aquifer of the Union County, Arkansas area: U.S. Geological Survey Fact Sheet 2004-3086, 4 p.

\section{— Rheannon M. Scheiderer and David A. Freiwald}

Any use of trade, product, or firm names is for descriptive purposes only and does not imply endorsement by the U.S. Government.

Information on technical reports and hydrologic data related to this study can be obtained from:

Director

U.S. Geological Survey

Arkansas Water Science Center

401 Hardin Road

Little Rock, AR 72211

Email: dc_ar@usgs.gov

Phone: (501) 228-3600

FAX: (501) 228-3601

World Wide Web: http://ar.water.usgs.gov/ 